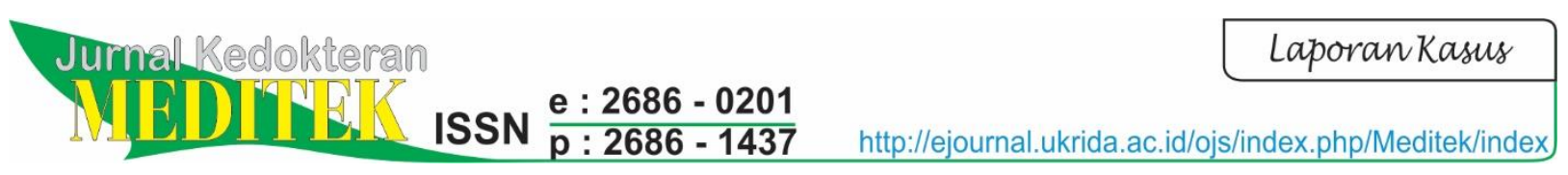

\title{
Penggunaan Norepinefrin pada Fase Dini Terapi Syok Sepsis dengan Gagal Ginjal Akut
}

\author{
Julian Welly Sualang, Ivy Jesslyn, Dennis Prakas
}

Rumah Sakit Umum Sumber Waras, Jakarta, Indonesia

Alamat Korespondensi: sualangjulian@gmail.com

\begin{abstract}
Abstrak
Laporan Kasus ini memberi gambaran penggunaan norepinephrine awal dalam penanganan syok sepsis. Studi kasus melaporkan pria 65 tahun dengan keluhan nyeri perut dan tidak buang air kecil sejak 1 malam sebelum keluhan. Pasien didiagnosis dengan syok sepsis disebabkan perforasi gaster. Infus Vasopressor diberikan bersama cairan kristaloid. Panduan Surviving Sepsis Campaign (SSC) tahun 2018 merekomendasi pemberian antibiotik spektrum luas, pemberian cairan kristaloid segera, pemberian vasopresor setelah resusitasi cairan. Umumnya, cairan intravena diberikan terlebih dahulu diikuti pemberian vasopressor, namun pemberian vasopressor yang lebih awal mampu memberikan hasil yang memuaskan. Hasil pemeriksaan darah menunjukan peningkatan kadar serum ureum dan kreatinin disertai penurunan laju filtrasi glomerulus. Hasil terapi pada pasien cukup memuaskan, pasien dapat pulang dengan kondisi perbaikan. Studi kasus menunjukan pemberian vasopressor awal memberikan hasil terapi yang baik pada penanganan syok sepsis.
\end{abstract}

Kata Kunci: gagal ginjal akut, syok sepsis, vasopressor

\section{Early Norepinephrine Infusion in Septic Shock with Acute Kidney Injury Treatment: a Case Report}

\begin{abstract}
This case illustrates the early use of norepinephrine in septic shock Acute Kidney Injury (AKI) treatment. Clinical presentation: a 65 year old male presented to the emergency room with an abdominal pain without urine output since a night before the admission. The patient was diagnosed with septic shock caused by perforated gaster. A vasopressor infusion was initiated early along with crystaloid infusions. The 2018 Surviving Sepsis Campaign (SSC) guidelines recommend broad-spectrum antibiotics, immediate administration of crystalloid fluids, and administration of vasopressors after fluid resuscitation. Generally, intravenous fluids are given first, followed by the vasopressor, but the initial administration of the vasopressor provided satisfactory results. Blood test results showed increased serum ureum and creatinine levels. Treatment outcome showed a significant improvement and patient was later discharged. The early vasopressor infusion shows a great promise in septic shock treatment.
\end{abstract}

Keywords: acute kidney injury, septic shock, vasopressor

\section{Pendahuluan}

Sepsis adalah respon disregulasi terhadap infeksi yang berlanjut pada kegagalan organ yang mengancam nyawa. ${ }^{1}$ Sepsis dipercaya sebagai salah satu penyebab primer dari kematian dan kondisi kritis secara global. Syok sepsis merupakan salah bentuk syok yang ditandai dengan abnormalitas sirkulasi, selular, dan metabolik yang terkait dengan risiko tinggi sepsis tanpa fase syok. ${ }^{2}$ Syok sepsis digambarkan sebagai vasodilatasi dan kebocoran vaskular yang meningkat akibat inflamasi sistemik yang dipicu oleh infeksi berat. ${ }^{3}$ Deteksi dini dan penanganan segera merupakan kunci dalam penanganan pasien dengan syok sepsis. ${ }^{4,5}$

Kejadian syok sepsis dan Acute Kidney Injury (AKI) dikaitkan dengan komplikasi yang lebih buruk dibandingkan dengan infeksi biasa, dengan angka kematian mencapai $70 \%$ yang tercatat dari 
beberapa literatur. ${ }^{6-10}$ Sepsis dengan AKI merupakan fenomena yang sering terjadi dan memengaruhi setengah dari sejumlah pasien kritis yang terdiagnosis dengan syok sepsis. ${ }^{6-10}$ Umumnya, cairan intravena diberikan terlebih dahulu, diikuti pemberian vasopressor saat tekanan darah target tidak tercapai meski volume intravaskular telah dioptimalkan. ${ }^{3}$

\section{Laporan Kasus}

Seorang laki-laki berusia 65 tahun datang ke IGD pada tanggal 3 Juni 2021 dengan keluhan nyeri perut pada seluruh lapang abdomen sejak 1 malam sebelum masuk rumah sakit. Keluhan disertai tidak bisa buang air besar (BAB) sampai napas terasa sesak. Pasien merasakan mual sampai nafsu makan yang berkurang. Tidak ada keluhan

Pemeriksaan laboratorium pada hari pertama menunjukan gangguan fungsi ginjal dengan hasil ureum $72 \mathrm{mg} / \mathrm{dL}$ dan kreatinin $2,5 \mathrm{mg} / \mathrm{dL}$ dengan LFG $49,2 \mathrm{~mL} / \mathrm{min} / 1,73 \mathrm{~m}^{2}$. Hasil pemeriksan darah demam, muntah darah, BAB cair darah ataupun hitam disangkal. Pasien memiliki riwayat penyakit hipertensi dan dislipidemia dengan pengobatan bisoprolol 1 x 5mg, amlodipin 1 x $10 \mathrm{mg}$, hidroklorotiazid 1x25mg, dan simvastatin $1 \mathrm{x}$ $20 \mathrm{mg}$. Kondisi pasien saat datang ke rumah sakit dengan kesadaran compos Mentis, tekanan darah 100/64 mmHg, frekuensi nadi 97x/menit lemah. Frekuensi pernapasan 30x/menit dengan saturasi 95\% dengan bantuan oksigen nasal kanul 5 liter per menit, suhu $37,3^{\circ} \mathrm{C}$. Pada pemeriksaan abdomen didapatkan bising usus terdengar hipoperistaltik dengan defans muscular pada seluruh lapang abdomen dan ekstremitas pada akral teraba dingin. Tidak ditemukan kelainan pada pemeriksaan neurologis. Observasi urin tidak keluar sejak 1 malam yang lalu.

rutin tidak menunjukan adanya kelainan. Hasil rontgen thorax menunjukan adanya gambaran udara bebas di bawah diafragma kanan (Gambar 1).

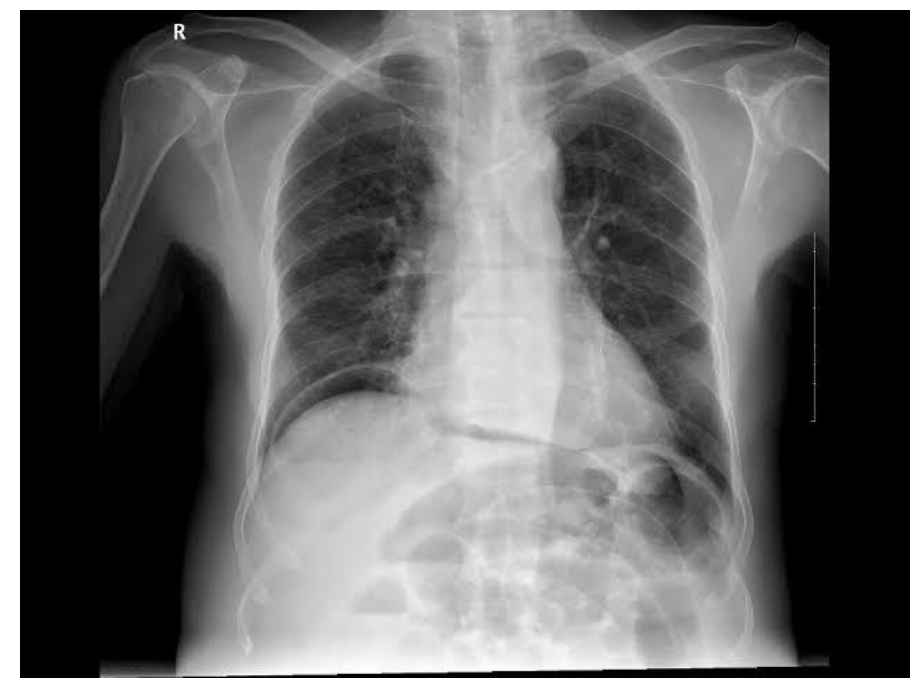

Gambar 1. Gambaran Free Air pada Rontgen Thorax

Pasien di Ruang IGD segera diberikan loading cairan kristaloid yaitu RL sebanyak $500 \mathrm{~mL}$ dalam 30 menit, pasien segera diberikan antibiotik, terapi dilanjutkan dengan pemberian norepinephrine drip sebanyak $0,05 \mathrm{mcg} / \mathrm{kg} / \mathrm{menit}$, loading cairan dilanjutkan sampai $1500 \mathrm{ml}$ sebelum dilakukan operasi laparotomi explorasi cito. Dijumpai perforasi gaster saat operasi (Gambar 2). Selama operasi, dilakukan peningkatan dosis norepinefrin sampai $0,3 \mathrm{mcg} / \mathrm{kg} / \mathrm{menit}$ dan ditambahkan drip Dobutamin $5 \mathrm{mcg} / \mathrm{kg} / \mathrm{menit}$. Pasca operasi pasien dirawat di ruang ICU dan didapatkan tensi yang tetap rendah yaitu 72/48 sehingga dilakukan dosis peningkatan titrasi pada norepinefrin sampai $0,6 \mathrm{mcg} / \mathrm{kg} / \mathrm{menit}$, dan dobutamine $10 \mathrm{mcg} / \mathrm{kg} / \mathrm{menit}$, pasien diberikan penambahan vasopressin dengan dosis $0,3 \mathrm{u}$. Pasien terintubasi pasca operasi dengan obat sedasi.

Pemeriksaan laboratorium hari kedua terdapat peningkatan kadar ureum yaitu $85 \mathrm{mg} / \mathrm{dL}$ dan kreatinin $2,6 \mathrm{mg} / \mathrm{dL}$. Produksi urin keluar sebanyak $0,7 \mathrm{~mL} / \mathrm{kg} / \mathrm{jam}$. 


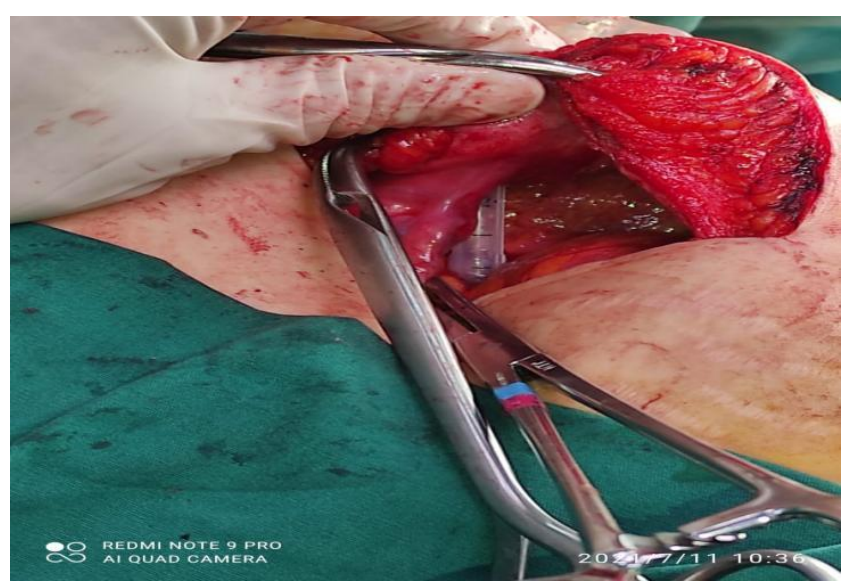

Gambar 2. Prosedur Laparotomi Segera Dilakukan pada Pasien dengan Diagnosis Syok Sepsis dengan Perforasi Gaster

Pada hari kedua dilakukan penggantian antibiotik. Tekanan darah pada hari ketiga mulai meningkat menjadi 139/89 dan stabil sehingga pemberian vasopresin dihentikan, dilakukan penurunan dosis norepinefrin sampai ke dosis $0,05 \mathrm{mcg} / \mathrm{kg} / \mathrm{menit}$, frekuensi nadi mencapai 110/menit sehingga dosis dobutamin diturunkan sampai ke dosis $7 \mathrm{mcg} / \mathrm{kg} / \mathrm{menit}$. Pada hari keempat terapi dilanjutkan, dilakukan prosedur weaning ventilator, dosis norepinefrin tetap diberikan pada $0,05 \mathrm{mcg} / \mathrm{kg} / \mathrm{menit}$, dan dosis dobutamin berangsur diturunkan. Pada hari kelima didapatkan tandatanda vital stabil sehingga dilakukan prosedur weaning ventilator. Dalam pemantauan didapatkan denyut jantung yang stabil, sehingga pemberian dobutamin dihentikan, pasca 4 jam monitoring, kondisi stabil sehingga penggunaan ventilator dihentikan, kondisi pasien membaik,sehingga dilakukan prosedur ekstubasi dan penghentian pemberian norepinefrin. Pada perawatan hari kelima dilakukan evaluasi laboratorium ulang dan didapatkan leukositosis dengan hasil leukosit $12,1 \times 10^{3} / \mu \mathrm{L}$, dan perbaikan kadar ureum dan kreatinin pasien, (ureum $50 \mathrm{mg} / \mathrm{dL}$, creatinin $1,2 \mathrm{mg} / \mathrm{dL}$ ). Hari keenam, kondisi pasien membaik, kesadaran kembali ke compos mentis, pasien dipindahkan dari ICU menuju ruang perawatan biasa, terapi dilanjutkan, dan pasien pulang setelah perawatan hari kesepuluh.

\section{Diskusi}

\footnotetext{
Panduan Surviving Sepsis Campaign (SSC) yang dipublikasikan tahun 2018 merekomendasikan pemberian antibiotik spektrum luas, pemberian cairan kristaloid segera $30 \mathrm{ml} / \mathrm{kg}$ untuk penanganan hipotensi atau bila kadar laktat $\geq 4 \mathrm{mmol} / \mathrm{L}$ dan pemberian vasopresor bila pasien mengalami hipotensi setelah dilakukan resusitasi cairan untuk menjaga MAP $\geq 65 \mathrm{mmHg}$ dalam 1
}

jam pertama. ${ }^{11}$ Patofisiologi syok sepsis cukup kompleks dan melibatkan vasodilatasi, hipovolemik baik secara absolut maupun relatif, disfungsi myocardial, peningkatan angka metabolik, dan gangguan aliran mikrovaskular.

Pada pasien dalam kasus ini didapatkan gambaran perforasi gaster dari rontgen thorax dengan kecurigaan kuat fokus infeksi didapatkan dari hasil pemeriksaan fisik di mana terdapat nyeri abdomen dengan defans pada seluruh lapang abdomen. Kondisi pasien dalam keadaan presyok, dengan perburukan kondisi ke arah sepsis, berdasarkan penilaian awal yaitu Q-SOFA skor pasien adalah 2 di mana tekanan darah sistolik < $100 \mathrm{mmHG}$ dengan laju pernapasan yang melebihi 22kali/menit. Berdasarkan penilaian skor SOFA, urin yang sudah tidak keluar dalam waktu 24 jam skor 4 sehingga diagnosis sepsis dapat ditegakkan. Dalam perjalanan penyakit tanda-tanda syok ditunjukan dalam perburukan kondisi di mana terjadi penurunan tekanan darah meski telah dilakukan loading cairan. Beberapa literatur menunjukan bahwa loading cairan secara agresif dapat berkontribusi dalam koreksi fase hipovolemia dan hipoperfusi pada fase awal sepsis terutama pada pasien dengan hemodinamik yang tidak stabil. ${ }^{12,13}$

Berdasarkan keluhan pasien, urin tidak keluar dalam kurun waktu kurang lebih selama 24 jam, kondisi ini menggambarkan gangguan ginjal yang disebabkan oleh penurunan perfusi ginjal akibat syok. Sepsis berat atau syok sepsis banyak terhubung atau menjadi penyebab terjadinya AKI. Penyebab terjadinya AKI pada syok sepsis disebabkan karena vasokonstriksi pada ginjal sehingga endotoxinemia merangsang terjadinya vasodilatasi sistemik dan venodilatasi, menyebabkan aktivasi sistem renin angiotensin disertai peningkatan sekresi vasokonstriksi dari arginin vasopresin. Aktivasi neurohormonal ini 
menyebabkan vaskokonstriksi pada ginjal dan iskemia ginjal sehingga berlanjut ke AKI. Gambaran AKI terlihat dari hasil darah pasien yaitu fungsi ginjal yang meningkat pada kadar Ureum yaitu $72 \mathrm{mg} / \mathrm{dL}$ creatinin $2,5 \mathrm{mg} / \mathrm{dL}$, dan EGFR yang menurun yaitu $49,2 \mathrm{~mL} / \mathrm{min} / 1,73 \mathrm{~m}^{2}$.

Deteksi awal dari sepsis yang dapat memicu terjadinya hipoperfusi jaringan merupakan salah satu kunci dalam penanganan pasien dengan septic shock. Studi implementasi terapeutik dalam sepsis bundle menjelaskan betapa pentingnya loading cairan awal dan membuat hal ini menjadi standar klinis. Namun, waktu pemberian vasopresor tidak dijelaskan. ${ }^{13}$ Rekomendasi dari kampanye sepsis menjelaskan penggunaan vasopresor dan treatment segera diberikan dalam 1 jam, termasuk setelah hipotensi yang mengancam jiwa untuk menjaga MAP >65mmHg. Meski konsep terapi inisiasi ini mendukung sepsis sebagai masalah darurat medis, namun pembuktian keberhasilan rekomendasi ini masih dipertanyakan. ${ }^{14}$ Waktu pemberian norepinefrin merupakan hal yang penting, salah satu rekomendasi menganjurkan pemberian norepinefrin dilakukan tanpa perlu menunggu selesainya koreksi cairan pada fase hipovolemik dalam penanganan syok sepsis. ${ }^{15}$ Pada kondisi pasien ini, pemberian cairan yang disertai dengan norepinefrine dilakukan segera setelah pasien diketahui dalam kondisi preshock dan diagnosis sepsis ditegakkan melalui SOFA scoring.

Dua studi menunjukan bahwa penggunaan norepinefrin awal dapat mengurangi jumlah pemberian cairan dan meningkatkan angka perbaikan. ${ }^{16,17}$ Beberapa keuntungan dalam pemberian norepinefrin lebih dini yaitu: meningkatkan kontraktilitas otot jantung, meningkatkan mikrosirkulasi yang dapat memicu perfusi pada syok sepsis, ${ }^{18-19}$ dan menunda kondisi koreksi hipotensi yang meningkatkan risiko kematian pada pasien sepsis. ${ }^{20-21}$ Pemberian cairan yang dilakukan sebanyak 500cc dalam 30 menit dan norepinefrin dosis $0,05 \mathrm{mcg} / \mathrm{kg} / \mathrm{menit}$ sambil pemberian cairan dilanjutkan sebanyak $1500 \mathrm{ml}$ sebelum dilakukan operasi. Selama operasi tekanan darah yang terus menurun sehingga dilakukan titrasi norepinefrin mencapai dosis $0,6 \mathrm{mcg} / \mathrm{kg} / \mathrm{jam}$ disertai dengan pemberian dobutamin memberikan hasil yang cukup baik ketika pasca operasi pasien memasuki ruang ICU dalam keadaan stabil. Sebuah studi menunjukan penggunaan norepinefrin yang lebih dini dapat mengurangi ketergantungan pada fase preload. ${ }^{22}$

Selama perawatan di ICU terjadi penurunan tekanan darah kembali sehingga diberikan terapi tambahan yaitu vasopresin sebanyak 0,3 unit.
Perbaikan kondisi pada hari kedua perawatan di mana output urine mancapai $0,7 \mathrm{cc} / \mathrm{kg} / \mathrm{jam}$. Kondisi pasien terus membaik dengan pemberian antibiotik dan terapi simtomatik tanpa dilakukan prosedur hemodialisis. Perawatan di ruang intensif selesai pada hari keenam perawatan dengan kondisi tekanan darah yang stabil, output urin yang normal, dan pasien dapat dilakukan prosedur weaning ventilator hingga ekstubasi.

\section{Simpulan}

Kondisi gawat darurat terkait syok sepsis dapat memicu pengambilan keputusan dalam penanganan syok yang lebih cepat, sehingga pemberian vasopresor pada pasien dengan syok sepsis dilakukan lebih awal saat inisiasi pemberian cairan secara cepat, sehingga akumulasi cairan berlebih bisa dikurangi, dan memperpendek masa hipotensi, pemberian vasopresor lebih dini menunjukan potensi manfaat yang lebih baik pada hasil perawatan pasien. Namun hal ini masih diperlukan penelitian lebih jauh untuk membuktikan hal tersebut.

\section{Ucapan Terima Kasih}

Penulis berterima kasih kepada dr. Ratin Sp.B, dr Eko Budi Prasetyo Sp. An, KIC, dr. Nicho Granada Sp.An, dr. Nency Martaria Sp.An, KNA, dr. Lucas Sp.An. untuk kontribusinya pada artikel ini.

\section{Daftar pustaka}

1. Singer M, Deutschman CS, Seymour CW, Shankar M, Annane D, Bauer M, et al. The third international consensus definitions for sepsis and septic shock (Sepsis-3). JAMA. 2016;315(8):801-10.

2. Torio CM, Andrews RM. National inpatient hospital costs: the most expensive conditions by payer, 2011. Statistical Brief \#160.Healthcare Cost and Utilization Project (HCUP) Statistical Briefs.2013. [cited 2021 oct 1]. Available from: http HCUP-US Statistical Briefs (ahrq.gov)

3. Angus DC, van der Poll T. Severe sepsis and septic shock. N Engl J M. 2013;3(69):840-51.

4. Rhodes A, Evans LE, Alhazzani W, Levy MM, Antonelli M, Ferrer R, et al. Surviving sepsis campaign: international guidelines for management of sepsis and septic shock: 2016. Crit Care Med. 2017;45(3):486-552. 
5. Cecconi M, De Backer D, Antonelli M, Beale $\mathrm{R}$, Bakker J, Hofer C, et al. Consensus on circulatory shock andhemodynamic monitoring. Task force of the European Society of IntensiveCare Medicine. Intensive Care Med. 2014;40(12):1795-815.

6. Alobaidi R, Basu RK, Goldstein SL, Bagshaw SM. Sepsis-associatedacute kidney injury. Semin Nephrol 2015;35:2-11.

7. Uchino S, Kellum JA, Bellomo R, Doig GS, Morimatsu $\mathrm{H}$, Morgera S,et al; Beginning and ending supportive therapy for the kidney (BEST Kidney) investigators. Acute renal failure in critically ill patients: amultinational, multicenter study. JAMA. 2005;294:813-8.

8. Bouchard J, Acharya A, Cerda J, Maccariello ER, Madarasu RC,Tolwani AJ, et al. A prospective international multicenter study of AKI in the intensive care unit. Clin J Am Soc Nephrol 2015;10:1324-31.

9. Bagshaw SM, Lapinsky S, Dial S, Arabi Y, Dodek P, Wood G, et al; Cooperative antimicrobial therapy of septic shock (CATSS) database research group. Acute kidney injury in septic shock: clinical outcomes and impact of duration of hypotension prior to initiation of antimicrobial therapy. Intensive Care Med 2009;35:871-81.

10. Fitzgerald JC, Basu RK, Akcan-Arikan A, Izquierdo LM, Piñeres Olave BE, Hassinger $\mathrm{AB}$, et al; Sepsis prevalence, outcomes, and therapies study investigators and pediatric acute lung injury and sepsis investigators network. Acute kidney injury in pediatric severe sepsis: an independent risk factor for death and new disability. Crit Care Med. 2016;44:2241-50.

11. Levy MM, Evans LE, Rhodes A. The surviving sepsis campaign bundle: 2018 update. Intensive Care Med. 2018;44(6):9258.

12. Smith SH, Perner A. Higher vs lower fluid volume for septic shock: clinical characteristics and outcome in unselected patients in a prospective, multicenter cohort. Crit Care. 2012;16:R76. https://doi.org/10.1186/cc11333

13. Russell JA, Gordon AC, Walley KR. Early may be better: early low-dose norepinephrine in septic shock. Am J Respir Crit Care Med. 2019;199(9):1049-51.

14. Finfer S, Liu B, Taylor C, Bellomo R, Cook D, Mcarthur C, et al. Resuscitation fluid use in critically ill adults: an international crosssectional study in 391 intensive care units. Crit
Care.

2010;14:R185.https://doi.org/10.1186/cc9293.

15. Peake SL, Delaney A, Bailey M, Bellomo R, Cameron PA, Cooper DJ, et al. Goal-directed resuscitation for patients with early septic shock. N Engl J Med. 2014;371(16):1496-506.

16. Ranjit S, Natraj R, Kandath SK, Kissoon N, Ramakrishnan B, Marik PE. Early norepinephrine decreases fluid and ventilatory requirements in pediatric vasodilatory septic shock. Indian J Crit Care Med. 2016;20(10):561-9.

17. Byrne L, Obonyo NG, Diab SD, Dunster KR, Passmore MR, Boon AC, et al. Unintended consequences: fluid resuscitation worsens shock in an ovine model of endotoxemia. Am J Resp Crit Care Med. 2018;198(8):1043-54.

18. Bai X, Yu W, Ji W, Lin Z, Tan S, Duan K, et al. Early versus delayed administration of norepinephrine in patients with septic shock. Crit Care. 2014;18(5):532.

19. Hamzaoui O, Jozwiak M, Geffriaud T, Sztrymf B, Prat D, Jacobs F, et al. Norepinephrine exerts an inotropic effect during the early phase of human septic shock. Br J Anaesth. 2018;120(3):517-24.

20. De Backer D, Pinsky M. Norepinephrine improves cardiac function duringseptic shock, but why? Br J Anaesth. 2018;120(3):421-4.

21. Maheshwari K, Nathanson BH, Munson SH, Khangulov V, Stevens M, Badani H, et al. The relationship between ICU hypotension and inhospital mortality and morbidity in septic patients. Intensive Care Med. 2018;44(6):85767.

22. Permpikul C, Tongyoo S, Viarasilpa $T$, Trainarongsakul T, Chakorn T, Udompanturak S. Early use of norepinephrine in septic shock resuscitation (CENSER). A randomized trial. Am J Respir Crit Care Med. 2019;199(9):1097-105. 